\title{
Comparison of Fuzzy-AHP and AHP in a spatial multi- criteria decision making model for urban land-use planning
}

\author{
Razieh Mosadeghi ${ }^{\mathrm{a}}$, Jan Warnken ${ }^{\mathrm{b}}$, Rodger Tomlinson ${ }^{\mathrm{a}} \&$ Hamid \\ Mirfenderesk $^{c}$ \\ ${ }^{a}$ Griffith Centre for Coastal Management, Griffith University, Parklands Drive, QLD 4222, Australia \\ ${ }^{\mathrm{b}}$ Australian Rivers Institute, Griffith University, Parklands Drive, QLD 4222, Australia \\ ${ }^{\mathrm{c}}$ Waterways and Flood Management, Gold Coast City Council, Nerang, QLD 4211, Australia
}

\begin{abstract}
Modern planning theories encourage approaches that consider all stakeholders with a variety of discourse values to avoid political and manipulative decisions. In the last decade, application of quantitative approaches such as Multi-criteria Decision Making techniques in land suitability procedures has increased, which allows handling heterogeneous data. The majority of these applications mainly used decision-making techniques to rank the priority of predefined management options or planning scenarios. The presented study, however, shows how spatial decision-making can be used not only to rank the priority of options and performing scenario analysis, but also to provide insight into the spatial extent of the alternatives. This is particularly helpful in situation where political transitions in regard to urban planning policies leave local decision-makers with considerable room for discretion. To achieve this, the study compares the results of two quantitative techniques (analytical hierarchy procedure (AHP) and Fuzzy AHP) in defining the extent of land-use zones at a large scale urban planning scenario. The presented approach also adds a new dimension to the comparative analysis of applying these techniques in
\end{abstract}

To cite this article: Razieh Mosadeghi, Jan Warnken, Rodger Tomlinson \& Hamid Mirfenderesk, 2015. Comparison of FuzzyAHP and AHP in a spatial multi-criteria decision making model for urban land-use planning, Journal of Computers, Environment and Urban Systems. 49 (2015), 54-65. DOI: 10.1016/j.compenvurbsys.2014.10.001 
urban planning by considering the scale and purpose of the decision-making. The result demonstrates that in the early stage of the planning process, when identifying development options as a focal point is required, simplified methods can be sufficient. In this situation, selecting more sophisticated techniques will not necessarily generate different outcomes. However, when planning requires identifying the spatial extent of the preferred development area, considering the intersection area suggested by both methods will be ideal.

Keywords: Land -use planning, Multi-criteria decision making, GIS, Analytic hierarchy process, Fuzzy AHP, Sensitivity analysis

\section{Introduction}

Urban planning analysis involves the consideration of a number of factors, including natural system constraints, compatibility with existing land uses, existing land use policies, and the availability of community facilities. The suitability techniques analyse the interaction between location, development actions, and environmental elements to classify the units of observation according to their suitability for a particular use (Collins et al., 2001; Kalogirou, 2002; Malczewski, 2004; Keshavarzi \& Heidari, 2010). In reality, not all the conflicting objectives due to economic development, community or conservation interests are always taken into consideration, which could lead to political and manipulative decisions (Albrechts and Denayer, 2001; Hillier, 2002). To avoid this, planners are encouraged to adjust their 'tool-kits' or mindsets to the changing needs and challenges of democratic society (Albrechts \& Denayer, 2001; Hillier, 2002). Modern planning theories such as communicative planning and actornetwork theory focus on the fact that effective planning decisions should essentially consider all

To cite this article: Razieh Mosadeghi, Jan Warnken, Rodger Tomlinson \& Hamid Mirfenderesk, 2015. Comparison of FuzzyAHP and AHP in a spatial multi-criteria decision making model for urban land-use planning, Journal of Computers, Environment and Urban Systems. 49 (2015), 54-65. DOI: 10.1016/j.compenvurbsys.2014.10.001 
participants with a variety of discourse types and values (Hillier, 2002). This encourages approaches for integrating very heterogeneous data, making them available to the various stakeholders to allow them to make more informed and less subjective decisions (Greene et al., 2010).

In the 1960s, the first Multi-Criteria Decision Making (MCDM) techniques emerged to alleviate difficulties in accommodating diverse opinions and handling large amounts of complex information in the decision-making process (Zopounidis \& Doumpos, 2002, Zopounidis and Pardalos, 2010). These capabilities have encouraged planners to combine MCDM with other planning tools such as geographical information system (GIS).

Multi-criteria decision making involves a multi-stage process of (i) defining objectives, (ii) choosing the criteria to measure the objectives, (iii) specifying alternatives, (iv) assigning weights to the criteria, and (v) applying the appropriate mathematical algorithm for ranking alternatives. MCDM allows to accommodate the need for unbiased integration of modern planning objectives for independent identification and ranking of the most suitable planning solutions (Herath \& Prato, 2006; Ananda \& Herath, 2009; Mosadeghi et al., 2009). These spatial MCDM techniques are capable of improving the transparency and analytic rigour of the land use decisions (Dunning et al., 2000; Hajkowicz \& Collins, 2006). Practical applications of such spatial MCDM techniques have become more widespread in land suitability studies (e.g. Chang et al., 2008; Chen et al., 2010; Greene et al., 2010; Arciniegas et al., 2011; Kordi \& Brandt, 2012). Recent study, however, shows application of MCDM techniques in identifying the extent of future land-use zones at local scale are rare (Mosadeghi et al., 2012). The majority of previous MCDM applications are at national, or regional scales and they mainly focus on using MCDM to

To cite this article: Razieh Mosadeghi, Jan Warnken, Rodger Tomlinson \& Hamid Mirfenderesk, 2015. Comparison of FuzzyAHP and AHP in a spatial multi-criteria decision making model for urban land-use planning, Journal of Computers, Environment and Urban Systems. 49 (2015), 54-65. DOI: 10.1016/j.compenvurbsys.2014.10.001 
rank the priority of predefined management options or planning scenarios (see e.g. Hajkowicz, 2002; Ananda and Herath, 2003; Qureshi and Harrison, 2003; Xevi and Khan, 2005; Hajkowicz and McDonald, 2006; Ananda and Herath, 2008; Hajkowicz, 2008; Kodikara, 2008; Bryanet al., 2009). Spatial MCDM, however, can be used not only to rank the priority of options and performing scenario analysis, but also to provide insight into the spatial extent of the alternatives (Arciniegas et al., 2011). This capability can assist local land use planners in identifying land-use zones for future urban development. It can be particularly useful in situations where planning instruments do not provide prescriptive guideline for local planning decisions. Therefore, presented approach here tries to encourage local governments to use more systematic approach to assist planners in integrating all environmental, social, economic, and political matters through a non-bias procedure. This study also examines the outcomes differences in applying two different techniques namely the AHP and Fuzzy AHP. As a result, it highlights the need for planners and decision-makers to make informed decisions about their choice of MCDM technique.

Several MCDM techniques have been proposed for combining with GIS analysis [e.g. ELECTRE-TRI in Joerin (2001); Ordered Weighted Averaging (OWA) in Malczewski (2006); Compromise programming in Baja et al. (2006); goal programming in Janssen et al. (2008); and analytical hierarchy procedure (AHP) ]. The AHP is one of the most commonly MCDM technique incorporated into GIS-based suitability procedures (e.g. Marinoni, 2004; Svoray et al., 2005; Ananda \& Herath, 2008; Chang et al., 2008; Thapa \& Murayama, 2008; Chen et al., 2010; Kordi \& Brandt, 2012).

To cite this article: Razieh Mosadeghi, Jan Warnken, Rodger Tomlinson \& Hamid Mirfenderesk, 2015. Comparison of FuzzyAHP and AHP in a spatial multi-criteria decision making model for urban land-use planning, Journal of Computers, Environment and Urban Systems. 49 (2015), 54-65. DOI: 10.1016/j.compenvurbsys.2014.10.001 
The popular AHP-based land-use suitability analyses have been criticized for their need for exact numerical values to express the strength of stakeholders' preferences (Deng, 1999; Mikhailov, 2003; Chang et al., 2008; Wang \& Chen, 2008; Kordi \& Brandt 2012; Mosadeghi et al., 2012). Such exact pair-wise comparison judgments may be impossible to determine and therefore arbitrary in many practical situations in urban environments with uncertainties arising from climate change, global economic crises or immigration policies and local population growth rates.

Advanced MCDM methods including ELECTRE, PROMETHEE, MAUT, Fuzzy set theory, and Random set theory provide more sophisticated algorithms to process uncertain or inaccurate information (Lahdelma et al., 2009; Zhang \& Achari, 2010; Figueira et al., 2010). The Fuzzy Set theory techniques are considered the most common techniques for dealing with imprecise and uncertain problems (Sui, 1992; Chen, 2005; Zarghami et al., 2008; Janssen et al., 2010; Keshavarzi \& Heidari, 2010; Zhang \& Achari, 2010; Demirel et al., 2009 ; Chen et al., 2011; Kordi \& Brandt, 2012; Mosadeghi et al., 2012). Most of the empirical studies however have applied Fuzzy techniques without a comparative analysis to investigate whether using more sophisticated techniques like Fuzzy AHP will truly make a significant difference compare to conventional AHP. On the other hand, the few studies that have done comparative analysis in land suitability applications (e.g. Hajkowics et al., 2000; Quadros et al., 2006; Ertuğrul, \& Karakaşoğlu, 2008; Elaalem et al., 2010; Kordi \& Brandt, 2012; Elaalem, 2013) have mainly focused on arithmetic aspects such as differences in criteria weights, option rankings, or the effects of introducing uncertainty into their models. This need for comparative analyses carries an even greater imperative in the context of applying spatial MCDM methods to real-world and Urban Systems. 49 (2015), 54-65. DOI: 10.1016/j.compenvurbsys.2014.10.001 
urban planning decisions, where transparency and simplicity of the decision-making model is a key element during consultation with the stakeholders. Accordingly, the presented research uses a case study to compare the outcomes of Analytical Hierarchy Process (AHP) and Fuzzy AHP in urban land use planning for the northeast Gold Coast located in Queensland on the east coast of Australia. In addition to the criteria ranking differences and sensitivity analysis, this study compares the spatial extent of the most preferred development locations suggested by both models. In other words, the comparative analysis in our study focuses more on the purpose of the application itself rather than just the technical aspects of the methods being used.

\section{Case Study: planning context and area}

This work compares the outcomes of different MCDM techniques in the context of urban expansion along a major transport corridor between the two largest cities in south-east Queensland; the Gold Coast and Brisbane. Much of the Gold Coast's southern areas are either already developed or designated as low residential density buffer areas adjoining a World Heritage Conservation Area and elevated terrain. The region's population growth in recent years has raised the need to identify new areas for future urban development. One of the potential development areas is the northeast of the Gold Coast that covers 17,250 hectares of coastal lowlands bounded by Logan River to the north, the Pacific Motorway (M1) to the west, and southern Moreton Bay to the east (Fig. 1).

The main land formation dominating this area is a coastal plain with agriculture, notably sugar cane, as the main economic activity in the area. In addition, extraction industries, aquaculture and tourism all play an important part in the economic growth of this region. The

To cite this article: Razieh Mosadeghi, Jan Warnken, Rodger Tomlinson \& Hamid Mirfenderesk, 2015. Comparison of FuzzyAHP and AHP in a spatial multi-criteria decision making model for urban land-use planning, Journal of Computers, Environment and Urban Systems. 49 (2015), 54-65. DOI: 10.1016/j.compenvurbsys.2014.10.001 
study area also contains a wide range of natural resources which, in combination with the area's strategic location and large agricultural land holdings, highlighted its exposition to a long history of major development pressures.

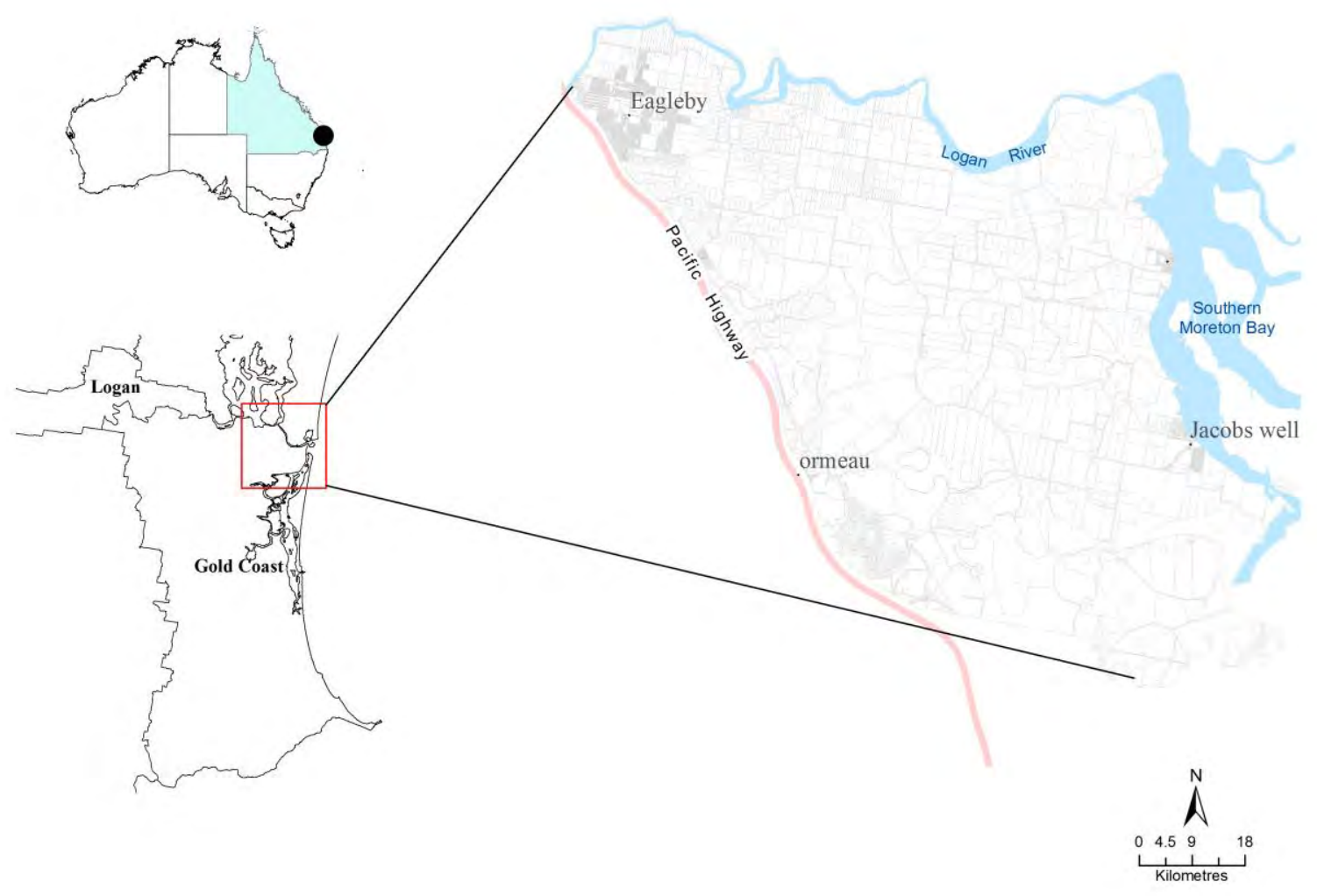

Fig.1. Location of the study area in southeast Queensland, Australia.

In 2012, a change in the State's Government prompted a major reform of the current coastal management and planning framework to revitalize an economy that had been stifled by a subdued global outlook and considerable local debts. The pre-2012 coastal planning system was built on a hierarchical layer of instruments guided by (a) management principles defined in a central document, the State Coastal Management Plan, and (b) detailed provisions in a set of regional coastal plans that contained maps of boundaries for 'coastal management district' areas.

To cite this article: Razieh Mosadeghi, Jan Warnken, Rodger Tomlinson \& Hamid Mirfenderesk, 2015. Comparison of FuzzyAHP and AHP in a spatial multi-criteria decision making model for urban land-use planning, Journal of Computers, Environment and Urban Systems. 49 (2015), 54-65. DOI: 10.1016/j.compenvurbsys.2014.10.001 
These provided direct links for integration with local planning schemes and the development approval process under the State's principal environmental planning legislation, the Sustainable Planning Act 2009 (QLD). On the other hand, the whole Queensland State Government's planning regulatory is also undergoing a reform with a trend toward more discretion approaches. The reform focuses on growth, development and economic prosperity and accordingly replaces all the prescriptive various existing policies by one new State Planning Policy. The existing planning policies currently provide decision-makers with detailed guideline on considering critical matters such as natural disasters, environmental constraints, and conservation aspects. Replacing these policies with one generalized policy will leave local governments with the power to make subjective and bias decisions. This situation makes the study area suitable for examining the capability of a spatial MCDM as a systematic approach to avoid political manipulative decisions.

\section{Analysis and results}

The methodology framework for this study was formulated in four main stages.

Stage 1: Define and rank land suitability criteria - which includes; (a) analysing the existing and emerging condition; (b) defining land suitability criteria; and (c) ranking the criteria.

Stage 2: Conduct GIS analysis- including determining the required GIS operations and developing digital maps for each criterion.

Stage 3: Generate land suitability maps- identifying most suitable areas of land for each land-use category using AHP and Fuzzy AHP.

To cite this article: Razieh Mosadeghi, Jan Warnken, Rodger Tomlinson \& Hamid Mirfenderesk, 2015. Comparison of FuzzyAHP and AHP in a spatial multi-criteria decision making model for urban land-use planning, Journal of Computers, Environment and Urban Systems. 49 (2015), 54-65. DOI: 10.1016/j.compenvurbsys.2014.10.001 
Stage 4: Compare and evaluate the differences between conventional and the Fuzzy AHP- this includes; comparative analysis of criteria ranking differences, differences in specifying the optimum location, options priority orders, overlay analysis of suitable areas and sensitivity analysis.

The first three stages are demonstrated in section 3 and section 4 outlines and discusses the comparison of the methods (Stage 4).

\subsection{Define and rank land suitability criteria}

In the first instance, the determination of land suitability criteria requires identification of principal land use types or categories relevant to the area of interest. A detailed analysis of relevant State, regional and local statutory planning instruments revealed a limited set of four main categories for urban development: 'residential', 'recreation', 'extractive industry', and 'marine industry', largely stipulated by the overruling provisions under the SEQ regional plan. Establishing the actual land suitability criteria for this study commenced with a comprehensive literature review; a compilation of strategic planning concepts of regional and local planning instruments (e.g. SEQ regional plan and Gold Coast Planning Scheme); and an analysis of the existing condition and availability of local datasets. . An aggregated set of the suitability criteria identified at two levels (main criteria and sub-criteria), for this study is presented in Table 1.

\subsubsection{Ranking land suitability criteria}

The MCDM preference process requires selected participants to rank the criteria based on pairwise comparisons. In this study these comparisons were obtained from a survey

To cite this article: Razieh Mosadeghi, Jan Warnken, Rodger Tomlinson \& Hamid Mirfenderesk, 2015. Comparison of FuzzyAHP and AHP in a spatial multi-criteria decision making model for urban land-use planning, Journal of Computers, Environment and Urban Systems. 49 (2015), 54-65. DOI: 10.1016/j.compenvurbsys.2014.10.001 
questionnaire to increase the robustness of the approach. Thirty-five questionnaires were distributed among a variety of experts including members of the local planning authority's Planning, Environment and Transport directorate as well as academic experts at national and local levels with a recognized knowledge of planning processes in Australia. Each participant was asked to rank the criteria and sub-criteria by referring to the numerical scale of $1-9$, with a score of 1 representing indifference between the two criteria and 9 representing absolute importance (Deng, 1999; Saaty \& Vargas, 2001; Mikhailov, 2003; Ananda \& Herath, 2008). Fourteen responses were received ( $40 \%$ response rate).

In the first phase, the data for pairwise comparisons were analysed using MATLAB ${ }^{\circledR}$ scripting based on AHP algorithms to obtain the final ranking for each criterion. The analysis was carried out using aggregated individual preferences, which were calculated based on geometric means of individual experts' ratings for each criterion. The geometric mean is consistent and upholds separability, unanimity and homogeneity which have to be satisfied to aggregate individual judgements (Ananda \& Herath, 2008). The Consistency Ratio (CR) was calculated by $C R=C I / R I(n)$ to evaluate the consistency of pairwise comparisons. Where CI is the consistency index given by $C I=\left(\lambda_{\max }-n\right) /(n-1), R I(n)$ is the random consistency index for matrices of order $n$ and $\lambda_{\max }$ is the principal eigenvalue of the judgment matrix.

In this study a standard CR threshold value of 0.10 was applied, i.e., if $\mathrm{CR}<0.10$, the pairwise comparison matrix has acceptable consistency and the weight values are valid and can be utilised (Saaty \& Vargas, 2001; Ananda \& Herath, 2008; Kordi \& Brandt, 2012). The

To cite this article: Razieh Mosadeghi, Jan Warnken, Rodger Tomlinson \& Hamid Mirfenderesk, 2015. Comparison of FuzzyAHP and AHP in a spatial multi-criteria decision making model for urban land-use planning, Journal of Computers, Environment and Urban Systems. 49 (2015), 54-65. DOI: 10.1016/j.compenvurbsys.2014.10.001 


\section{pairwise comparisons in this study were consistent with the overall mean consistency ratio (CR)}

\section{for all four categories of $<0.005$.}

Table 1. Land suitability criteria.

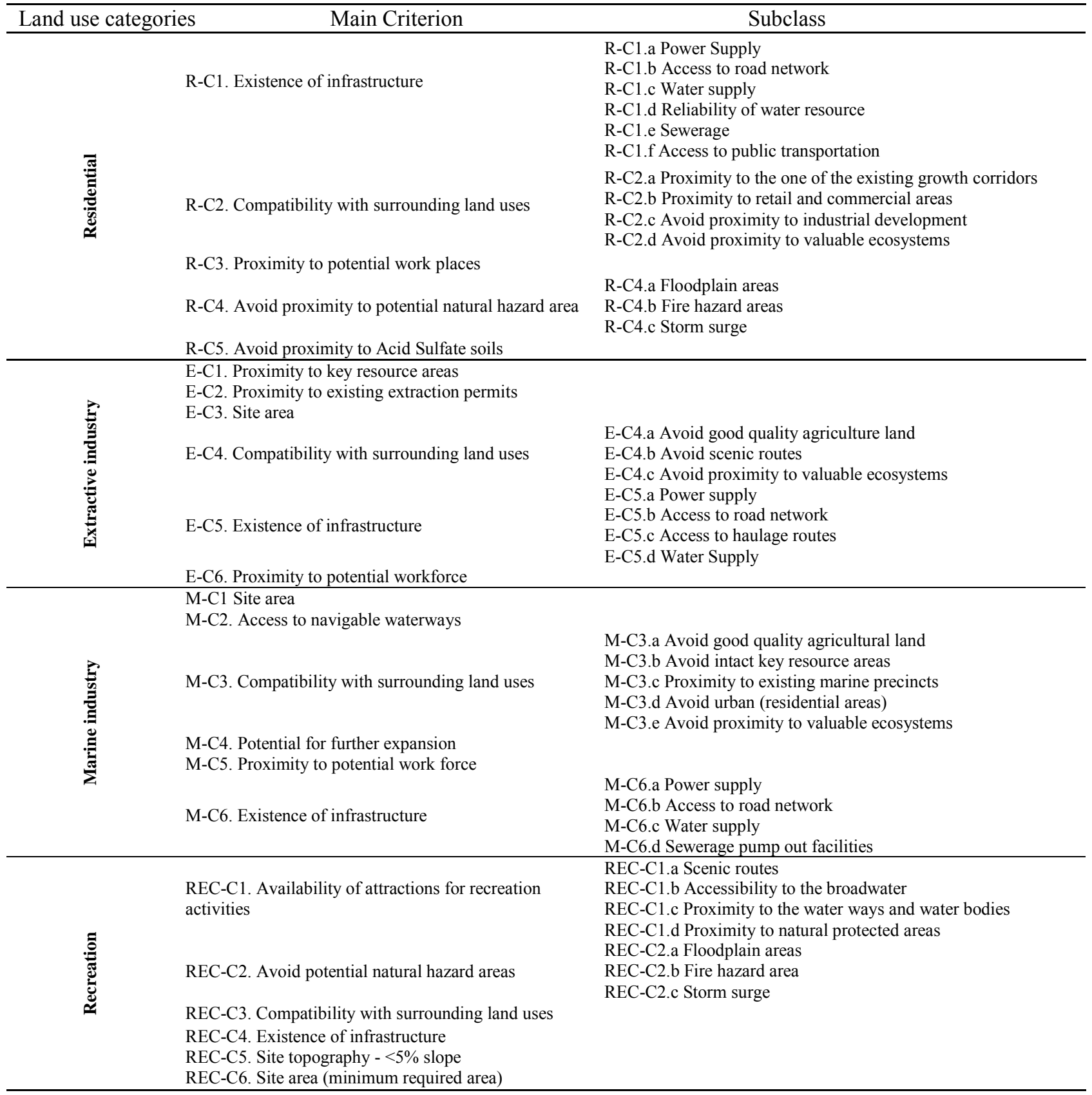

To cite this article: Razieh Mosadeghi, Jan Warnken, Rodger Tomlinson \& Hamid Mirfenderesk, 2015. Comparison of FuzzyAHP and AHP in a spatial multi-criteria decision making model for urban land-use planning, Journal of Computers, Environment and Urban Systems. 49 (2015), 54-65. DOI: 10.1016/j.compenvurbsys.2014.10.001 
Alternatively, Fuzzy AHP was also used in this research to incorporate uncertainties in the decision maker's opinions. Fuzzy AHP uses a range of values and, from this range; decision makers can select the value that reflects their confidence. They can also specify their attitude as optimistic, pessimistic or moderate. Optimistic attitude is represented by selecting the highest value of the range, moderate attitude is represented by the middle value of the range and pessimistic attitude is represented by the lowest value of the range (Jie et al., 2006; Demirel et al., 2009).

The Fuzzy AHP weights used for this work were calculated based on Chang's extent analysis method (Chang, 1996). Following section outlines the extent analysis method:

Let $X=\left\{x_{1}, x_{2}, \ldots, x_{n}\right\}$ be an object set (land-use options in our study) and $U=\left\{u_{1}, u_{2}, \ldots, u_{n}\right\}$ be a goal set (land suitability criteria). $m$ extent analysis values for each object can be obtained as $M_{g i}^{1}, M_{g i}^{2}, \ldots, M_{g i}^{m}, \quad i=1,2, \ldots, m$ where $M_{g i}^{j}$ is a triangular fuzzy number (Chang, 1996; Haghighi et al., 2010). $M_{g i}^{j}$ is defined by a triplet $(l, m, u)$. The triangular fuzzy number is based on a three-value judgment: the minimum possible value $l$, the most possible value $m$ and the maximum possible value $u$. The membership function is defined as (Ertuğrul \& Karakaşoğlu, 2007; Wu et al., 2004; Deng, 1999):

$$
\mu_{\tilde{\alpha}}(x)=\left\{\begin{array}{l}
\left(x-l_{j}\right) /\left(m_{j}-l_{j}\right), l_{j} \leq x \leq m_{j} \\
(x-u) /\left(m_{j}-u_{j}\right), m_{j} \leq x \leq u_{j} \\
0, \text { otherwise }
\end{array}\right\}
$$

The next step is to find the value of Fuzzy synthetic extent with respect to $i^{\text {th }}$ object:

To cite this article: Razieh Mosadeghi, Jan Warnken, Rodger Tomlinson \& Hamid Mirfenderesk, 2015. Comparison of FuzzyAHP and AHP in a spatial multi-criteria decision making model for urban land-use planning, Journal of Computers, Environment and Urban Systems. 49 (2015), 54-65. DOI: 10.1016/j.compenvurbsys.2014.10.001 


$$
S_{i}=\sum_{j=1}^{m} M_{g i}^{j} \otimes\left[\sum_{i=1}^{n} \sum_{j=1}^{m} M_{g i}^{j}\right]^{-1}
$$

where product $\otimes$ and inverse of a Fuzzy number are defined as:

$$
M_{1} \otimes M_{2}=\left(l_{1} l_{2}, m_{1} m_{2}, u_{1} u_{2}\right)
$$

$$
M^{-1}=(1 / u, 1 / m, 1 / l)
$$

Then the degree of possibility of $M_{1} \geq M_{2}$ should be determined, which is defined as:

$V\left(M_{1} \geq M_{2}\right)=\operatorname{hgt}\left(M_{1} \cap M_{2}\right)=\frac{l_{1}-u_{2}}{\left(m_{2}-u_{2}\right)-\left(m_{1}-l_{1}\right)}$

The degree of possibility for a convex Fuzzy number to be greater than $K$ convex Fuzzy numbers $M_{i}(i=1,2, \ldots, k)$ can be defined by:

$V\left(M \geq M_{1}, M_{2}, \ldots, M_{K}\right)=V\left[\left(M \geq M_{1}\right) \operatorname{and}\left(M \geq M_{2}\right)\right.$ and $\ldots$ and $\left.\left(M \geq M_{k}\right)\right]=$ $\min V\left(M \geq M_{i}\right), i=1,2,3, \ldots, k$.

Assuming that

$d^{\prime}\left(A_{i}\right)=\min V\left(S_{i} \geq S_{k}\right)$

For $k=1,2, . ., n ; k \neq i$ the weight vector $W^{\prime}$ and normalized weight vector $W$ are given by

$$
\begin{aligned}
& W^{\prime}=\left(d^{\prime}\left(A_{1}\right), d^{\prime}\left(A_{2}\right), \ldots, d^{\prime}\left(A_{n}\right)\right)^{T} \\
& W=\left(d^{\prime}\left(A_{1}\right), d^{\prime}\left(A_{2}\right), \ldots, d^{\prime}\left(A_{n}\right) / \sum_{i=1}^{n} d^{\prime}\left(A_{i}\right)\right)
\end{aligned}
$$

To cite this article: Razieh Mosadeghi, Jan Warnken, Rodger Tomlinson \& Hamid Mirfenderesk, 2015. Comparison of FuzzyAHP and AHP in a spatial multi-criteria decision making model for urban land-use planning, Journal of Computers, Environment and Urban Systems. 49 (2015), 54-65. DOI: 10.1016/j.compenvurbsys.2014.10.001 
where $A_{i}(i=1,2, \ldots, n)$ are $n$ elements, which show the appropriateness of object set $X$. It is important to note that weight vector $W^{\prime}$ and $W$ are non-Fuzzy numbers and represent the suitability of each option (object) with respect to the criteria (goals).

Finally, adding the weights per option multiplied by the weights of the corresponding criteria gives the final score for each option (Chang, 1996). Table 2 shows calculated priority weights in AHP and Fuzzy AHP for the residential category.

Table 2. AHP and Fuzzy AHP priority weights for the residential category (example)

\begin{tabular}{|c|c|c|c|c|c|c|c|}
\hline \multirow{3}{*}{ Criteria } & \multicolumn{2}{|c|}{ AHP } & \multicolumn{5}{|c|}{ Fuzzy AHP } \\
\hline & \multirow{2}{*}{$\begin{array}{c}\text { Local } \\
\text { weights }\end{array}$} & \multirow{2}{*}{$\begin{array}{l}\text { Global } \\
\text { weights }\end{array}$} & \multicolumn{3}{|c|}{ Triangular Numbers } & \multirow{2}{*}{$\begin{array}{l}\text { Local } \\
\text { weights }\end{array}$} & \multirow{2}{*}{$\begin{array}{c}\text { Global } \\
\text { weights }\end{array}$} \\
\hline & & & lower & middle & upper & & \\
\hline $\mathrm{R}-\mathrm{C} 4$ & 0.3853 & & 0.3772 & 0.603 & 0.8457 & 0.2829 & \\
\hline $\mathrm{R}-\mathrm{C} 2$ & 0.2475 & & 0.0854 & 0.175 & 0.4397 & 0.2335 & \\
\hline $\mathrm{R}-\mathrm{C} 1$ & 0.1924 & & 0.0463 & 0.094 & 0.2451 & 0.2073 & \\
\hline $\mathrm{R}-\mathrm{C} 3$ & 0.1320 & & 0.0231 & 0.034 & 0.0671 & 0.0859 & \\
\hline R-C5 & 0.0428 & & 0.0463 & 0.094 & 0.1315 & 0.1903 & \\
\hline \multicolumn{8}{|l|}{ Sub Criteria } \\
\hline $\mathrm{R}-\mathrm{C} 1 . \mathrm{d}$ & 0.3109 & 0.0598 & 0.1238 & 0.307 & 0.7436 & 0.2061 & 0.0427 \\
\hline R-C1.c & 0.2664 & 0.0513 & 0.1313 & 0.345 & 0.8428 & 0.2081 & 0.0431 \\
\hline $\mathrm{R}-\mathrm{C} 1 . \mathrm{f}$ & 0.2216 & 0.0426 & 0.0327 & 0.082 & 0.2644 & 0.1558 & 0.0323 \\
\hline R-C1.b & 0.1088 & 0.0209 & 0.0402 & 0.149 & 0.4131 & 0.1817 & 0.0377 \\
\hline R-C1.e & 0.0576 & 0.0111 & 0.0327 & 0.082 & 0.2644 & 0.1558 & 0.0323 \\
\hline $\mathrm{R}-\mathrm{C} 1 . \mathrm{a}$ & 0.0345 & 0.0066 & 0.0177 & 0.034 & 0.1157 & 0.0924 & 0.0192 \\
\hline R-C2.a & 0.3941 & 0.0975 & 0.1417 & 0.293 & 0.6171 & 0.3109 & 0.0726 \\
\hline $\mathrm{R}-\mathrm{C} 2 . \mathrm{d}$ & 0.3223 & 0.0798 & 0.2778 & 0.523 & 1.0467 & 0.3459 & 0.0808 \\
\hline $\mathrm{R}-\mathrm{C} 2 . \mathrm{b}$ & 0.2397 & 0.0593 & 0.0288 & 0.070 & 0.1019 & 0.1355 & 0.0316 \\
\hline $\mathrm{R}-\mathrm{C} 2 . \mathrm{c}$ & 0.0438 & 0.0108 & 0.0447 & 0.114 & 0.2629 & 0.2078 & 0.0485 \\
\hline R-C4.c & 0.4818 & 0.1857 & 0.0985 & 0.291 & 0.8197 & 0.3675 & 0.1040 \\
\hline R-C4.a & 0.4646 & 0.1790 & 0.2239 & 0.606 & 1.5222 & 0.4153 & 0.1175 \\
\hline R-C4.b & 0.0535 & 0.0206 & 0.0600 & 0.103 & 0.2728 & 0.2172 & 0.0614 \\
\hline
\end{tabular}

To cite this article: Razieh Mosadeghi, Jan Warnken, Rodger Tomlinson \& Hamid Mirfenderesk, 2015. Comparison of FuzzyAHP and AHP in a spatial multi-criteria decision making model for urban land-use planning, Journal of Computers, Environment and Urban Systems. 49 (2015), 54-65. DOI: 10.1016/j.compenvurbsys.2014.10.001 


\subsection{GIS analysis}

The second step focused on compiling a GIS database incorporating land use and environmental constraints. Existing land use classifications were extracted from the current national land use map modified for regional conditions (1:50,000 QLUMP data, Queensland Government, 2012) and strategic base maps used for the area's planning scheme. This included good quality agricultural lands; potential bushfire hazard areas; natural wetland and waterway areas; acid sulphate soil hazard area; extractive resources; conservation strategy plan areas; infrastructure provision and sequencing strategy; tourism strategy; public transport system and; flood affected areas.

Raster data analysis was used to create suitability models because spatial analyses can be performed on several raster layers at once. Since most of the base maps used in this study were in vector format, many layers were converted to raster maps. The ArcGIS 10.0 software was used to prepare the spatial layers in land suitability model. For example, maps with nonnumerical attributes (such as land use map, fire hazard areas, flood affected areas etc.) were transformed into ordinal maps by using "Reclassify" function. In some cases, distance maps were created and then rectified to a common scale of 1-10, giving higher values to more suitable attributes.

\subsection{Land suitability maps}

The final output of a spatial MCDM approach is a series of maps delineating areas most suitable for each land use category. In this study the land suitability maps were formulated based on the sieve mapping overlay technique. 
After computing the priority weights for each dataset (suitability criterion), each layer, representing each criterion, was multiplied by its AHP and Fuzzy-AHP weight separately. A weighted linear combination equation $\left(L S=\sum_{i=1}^{n} W_{i}\right)$ was formulated and used to combine layers to derive a final suitability map. In this formula LS is the suitability for particular land-use; $n$ is the number of evaluated criteria and; $W_{i}$ is the weight of each criterion.

The resultant maps show spatial patterns and distributions of the most suitable land for further development. Five suitability classes were identified in this study with the cut-off values based on the fundamental scale of AHP and Fuzzy AHP. Subsequently, these five suitability classes were defined as: (S1) highly suitable cells with weights $>7$; (S2) suitable cells with weights $>6$ and $\leq 7$; (S3) moderately suitable cells with weights $>5$ and $\leq 6$; (S4) marginally suitable cells with weights $>4$ and $\leq 5$; and $(N)$ unsuitable cells with weights $<4$. The final Fuzzy AHP and AHP maps were subsequently reclassified in ArcGIS based upon their five suitability classes and converted to polygon layers. The highest suitability class was then selected and considered as the candidate options for each particular category as shown in Fig 2 for residential use according to AHP and Fuzzy AHP models.

\section{Comparative analysis}

The differences in outcomes between AHP and Fuzzy AHP approaches were compared on several levels: (i) divergence of criteria ranks for each MCDM method, (ii) the extent and location of the preferred option for further development (spatial overlay analysis), (iii) the relative influence of each criterion in each model (standard sensitivity analysis). 


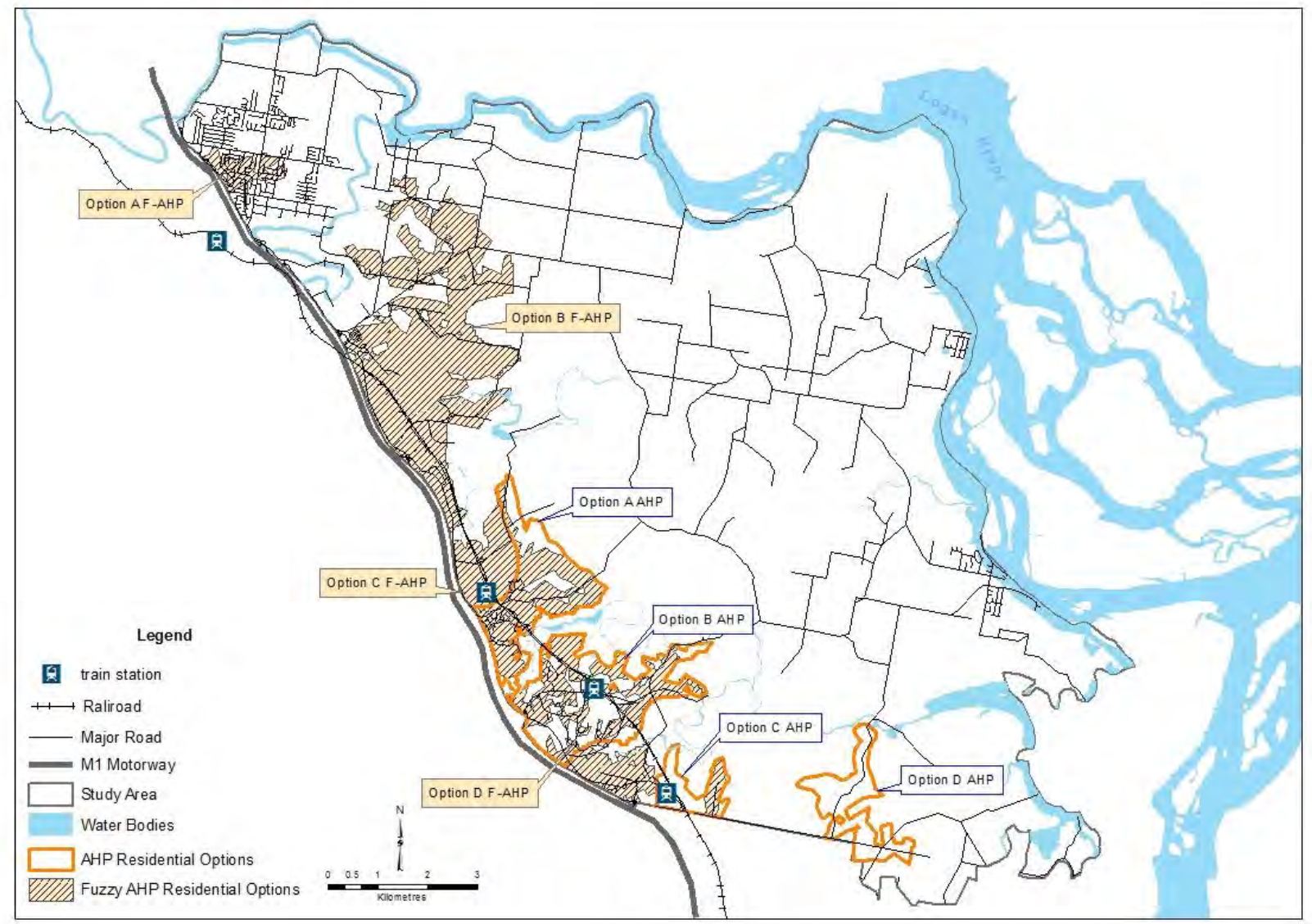

Fig. 2. Residential candidate options in the AHP and Fuzzy AHP models.

\subsection{Comparison of the criteria ranking}

The critical input to the spatial MCDM model is the criteria ranking order assigned according to the relative importance weight of each criterion. The results of this study showed differences in the final weights derived from each MCDM algorithm. To evaluate whether these divergences caused differences in the influence of each criterion on the final outcomes of the model the percentage influence of each criterion was calculated as below:

Percentage Influence $=100 * \frac{W_{i}}{\sum_{i=1}^{n} w_{i}}$

To cite this article: Razieh Mosadeghi, Jan Warnken, Rodger Tomlinson \& Hamid Mirfenderesk, 2015. Comparison of FuzzyAHP and AHP in a spatial multi-criteria decision making model for urban land-use planning, Journal of Computers, Environment and Urban Systems. 49 (2015), 54-65. DOI: 10.1016/j.compenvurbsys.2014.10.001 
where $w_{i}$ is the global weight given to $C_{i}$ and $n$ is the total number of criteria in each category.

From the criteria ranking order it appears that there are differences between the results of the AHP and Fuzzy AHP models.

In the 'residential' category, the differences between the main criteria were not significant. For instance, R-C4 was ranked as the most important criteria by both AHP and Fuzzy AHP, followed by $\mathrm{R}-\mathrm{C} 1$ and $\mathrm{R}-\mathrm{C} 2$. The AHP model assigned R-C5 as the least important criterion, while Fuzzy AHP assigned R-C3 last. The differences became more apparent at the sub-criteria level. For example, R-C1 sub-criteria revealed completely different sequences for AHP and Fuzzy AHP, respectively. Further, R-C1.e and R-C1.f were assigned the same ranks by Fuzzy AHP.

In the 'extractive industry' category, the main criteria rankings were different in the AHP and Fuzzy AHP models (with the exception of E-C2); however, the sub-criteria orders of importance were exactly the same in both models. This suggests that the respondents were more confident assigning criteria weights in this category. Accordingly using Fuzzy set theory to consider uncertainty resulted in the same outcome as for traditional AHP.

The differences between AHP and Fuzzy AHP in the marine category were more pronounced (Table 3). The biggest divergence was in the main criteria ranking of $\mathrm{M}-\mathrm{C} 4, \mathrm{M}-\mathrm{C} 5$ and, M-C6, which were assigned the same weights and rank in the Fuzzy AHP model and different weights in the AHP model. This is due to the Fuzzy AHP algorithm moderating the experts' judgments by considering triangular fuzzy numbers instead of a single number for each criterion weight while in the AHP model extreme weights assigned by one expert can have a big 
influence on the final weight. Sub-criteria weights in this category were slightly different but not as significantly difference as the main criteria.

Table 3 Comparison of the criteria ranking in the marine industry category

\begin{tabular}{|c|c|c|c|c|c|c|}
\hline \multirow{2}{*}{ Criteria } & \multicolumn{3}{|c|}{ AHP Results } & \multicolumn{3}{|c|}{ Fuzzy AHP Results } \\
\hline & Weight & Rank & \% Influence & Weight & Rank & $\%$ Influence \\
\hline M-C1 & 0.1137 & 5 & 10.70 & 0.1727 & 3 & 17.27 \\
\hline M-C2 & 0.2082 & 1 & 31.75 & 0.2167 & 1 & 21.67 \\
\hline M-C3 & 0.1908 & 2 & See C3 sub-criteria & 0.2034 & 2 & See C3 sub-criteria \\
\hline M-C4 & 0.1839 & 3 & 17.99 & 0.1357 & 4 & 13.57 \\
\hline M-C5 & 0.1318 & 6 & 3.53 & 0.1357 & 4 & 13.57 \\
\hline M-C6 & 0.1717 & 4 & See C6 sub-criteria & 0.1357 & 4 & See C6 sub-criteria \\
\hline \multicolumn{7}{|c|}{ C3 Sub-criteria } \\
\hline M-C3.a & 0.049 & 4 & 4.90 & 0.0411 & 3 & 4.11 \\
\hline M-C3.b & 0.007 & 5 & 0.70 & 0.0247 & 5 & 2.47 \\
\hline M-C3.c & 0.051 & 2 & 5.10 & 0.0372 & 4 & 3.72 \\
\hline M-C3.d & 0.050 & 3 & 5.00 & 0.0465 & 2 & 4.65 \\
\hline M-C3.e & 0.059 & 1 & 5.90 & 0.0540 & 1 & 5.40 \\
\hline \multicolumn{7}{|c|}{ C6 Sub-criteria } \\
\hline M-C6.a & 0.007 & 4 & 0.70 & 0.0411 & 2 & 4.11 \\
\hline M-C6.b & 0.062 & 1 & 6.20 & 0.0432 & 1 & 4.32 \\
\hline M-C6.c & 0.051 & 2 & 5.10 & 0.0335 & 3 & 3.35 \\
\hline M-C6.d & 0.025 & 3 & 2.50 & 0.0179 & 4 & 1.79 \\
\hline
\end{tabular}

The results of the 'recreation' category were similar to those of the 'marine industry' with similar weights assigned to some main criteria (REC-C2 and REC-C3). However, differences between sub-criteria were less noticeable than those of the marine industry with sub-criteria in REC-C1, REC-C2 and, REC-C4 in exactly the same order.

To cite this article: Razieh Mosadeghi, Jan Warnken, Rodger Tomlinson \& Hamid Mirfenderesk, 2015. Comparison of FuzzyAHP and AHP in a spatial multi-criteria decision making model for urban land-use planning, Journal of Computers, Environment and Urban Systems. 49 (2015), 54-65. DOI: 10.1016/j.compenvurbsys.2014.10.001 
Although comparisons between the AHP and Fuzzy AHP criteria weights and rankings show some differences they do not identify how these differences affected the final decision. Therefore, the next step was to compare the output maps of each model to identify whether the differences in ranking order resulted in differences between model outcomes.

\subsection{Comparison of the suitability maps}

The land suitability maps exhibited some differences in specifying the optimum location for the different land-use categories. In some categories, such as the extractive industry, the differences were small while for residential land-use the differences were significant. This is consistent with the ranking results with the differences in criteria weighting following the same patterns. These differences are due to differences in the weights imported in the Spatial MCDM tool using AHP and Fuzzy AHP. A quantitative comparison of the differences in suitability is summarized in Table 4. According to the results, only a small portion of the study area is classified as highly suitable (S1) for further development. This area is about $8 \%$ in the AHP model and 13\% in the Fuzzy AHP model for residential land-use. These suitability values are due to the existing growth corridors and infrastructure located mainly in the western section of the study area. Unsuitable area $(\mathrm{N})$ in the residential category covers about $5.35 \%$ and $1.21 \%$ of land area in the AHP and Fuzzy AHP, respectively. Most of this unsuitable area is located in the eastern and central sections of the study area where floodplains dominate.

The areas identified as the highest suitability class (S1) were then selected and considered as the candidate options for each land-use category. Next, the AHP and Fuzzy AHP models were used to rank the suitability of each option or alternative. The option ranking order is calculated based on the criteria weights and pairwise comparisons between alternatives in regard to each

To cite this article: Razieh Mosadeghi, Jan Warnken, Rodger Tomlinson \& Hamid Mirfenderesk, 2015. Comparison of FuzzyAHP and AHP in a spatial multi-criteria decision making model for urban land-use planning, Journal of Computers, Environment and Urban Systems. 49 (2015), 54-65. DOI: 10.1016/j.compenvurbsys.2014.10.001 
criterion. Spatial distribution and priority order of these options were then evaluated and compared in the two models.

Table 4 Comparison of the suitability differences in AHP and Fuzzy AHP models

\begin{tabular}{|c|c|c|c|c|c|c|c|c|}
\hline \multirow{2}{*}{ Land-use } & \multirow{2}{*}{$\begin{array}{l}\text { MCDM } \\
\text { technique }\end{array}$} & \multicolumn{5}{|c|}{ Area km ${ }^{2}$} & \multirow{2}{*}{$\begin{array}{c}\text { Highest } \\
\text { suitability } \\
\text { value }\end{array}$} & \multirow{2}{*}{$\begin{array}{c}\text { \% most suitable area } \\
\text { /total area }\end{array}$} \\
\hline & & S1 & S2 & S3 & S4 & $\mathbf{N}$ & & \\
\hline \multirow{2}{*}{ Residential } & AHP & 13.80 & 52.54 & 91.25 & 14.63 & 9.78 & 7.96 & $7.58(\mathrm{~S} 1)$ \\
\hline & Fuzzy AHP & 23.00 & 35.35 & 32.22 & 81.31 & 2.22 & 7.73 & $12.64(\mathrm{~S} 1)$ \\
\hline Extractive & AHP & 0 & 11.63 & 54.16 & 89.88 & 18.49 & 6.93 & $6.39(\mathrm{~S} 2)$ \\
\hline Industry & Fuzzy AHP & 0 & 0 & 0 & 14.00 & 160.08 & 5.02 & 7.69 (S4) \\
\hline Marine & AHP & 0 & 0 & 7.85 & 82.023 & 84.27 & 5.56 & $3.31(\mathrm{~S} 3)$ \\
\hline Industry & Fuzzy AHP & 0 & 0 & 12.36 & 97.04 & 64.74 & 5.77 & $6.79(\mathrm{~S} 3)$ \\
\hline \multirow{2}{*}{ Recreation } & AHP & 0 & 5.94 & 120.17 & 47.21 & 0.0159 & 6.45 & $3.26(\mathrm{~S} 2)$ \\
\hline & Fuzzy AHP & 6.44 & 96.92 & 68.76 & 1.24 & 0 & 7.53 & 3.54 (S4) \\
\hline
\end{tabular}

(S1) highly suitable cells with weights higher than 7;

(S2) suitable cells with weights between 6 and 7;

(S3) moderately suitable cells with weights between 5 and 6;

(S4) marginally suitable cells with weights between 4 and 5;

(N) unsuitable cells with weights less than 4.

As shown in Fig. 2 four candidate options were identified by each model for the residential category. Areas around Ormeau development and Ormeau train station were identified by both models. In addition to these areas, the AHP model suggested areas around Pimpama and Yawalpah Road, while small land parcels in Eagleby and Stapylton were considered suitable options by the Fuzzy AHP model. In both models the areas around Ormeau

To cite this article: Razieh Mosadeghi, Jan Warnken, Rodger Tomlinson \& Hamid Mirfenderesk, 2015. Comparison of FuzzyAHP and AHP in a spatial multi-criteria decision making model for urban land-use planning, Journal of Computers, Environment and Urban Systems. 49 (2015), 54-65. DOI: 10.1016/j.compenvurbsys.2014.10.001 
(option A in the AHP and option C in Fuzzy AHP) were ranked the most suitable option for residential development.

The AHP and Fuzzy AHP both showed strong consistency by identifying two candidate options for extractive industry. The options in these models not only cover the same area but were also ranked in the same order with option A, identified as the first priority for future development by both models.

In marine industry the candidate options in both models were distributed slightly differently. Although three options were selected by the Fuzzy AHP model and two by the AHP model, option B and C in the Fuzzy AHP model mainly cover the same area as option A and B in the AHP model. Both models considered the area adjacent to the existing marine precinct as the first priority for marine industry expansion. Option A in the Fuzzy AHP model covers the key resource area (KRA 65A1) located in the northern section of the study area.

The outputs of the two models identified several candidate options for recreational activities within the study area. In both models six options were identified, however, the ranking orders of the models were slightly different. For example while option B was the best option in the Fuzzy AHP model, it was ranked second in the AHP model. The AHP model assigned option D as the most suitable option. Table 5 summarises the option priority weights in both models.

\subsection{Sensitivity analysis}

In the third step, sensitivity Analysis (SA) was undertaken to examine the robustness and reliability of the choice option in each model. In this study, the correlation coefficient was calculated for 'criteria weight changes' and 'selection of the suitable options for land development' as a measure of sensitivity (as suggested in Saltelli et al., 2000; Cacuci et al., 2003; 
Saltelli et al., 2004). In other words, sensitivity analysis was undertaken to determine the degree to which options (especially the best option) were sensitive to the criteria weight changes. Greater correlation coefficient indicates a higher degree of sensitivity in the outputs. To apply criteria weight changes into the correlation coefficient calculation, a range of $\pm 50 \%$ weight deviations with a $1 \%$ increment of change was applied to simulation runs in MATLAB ${ }^{\circledR}$. Fig. 3 illustrates the result of sensitivity analysis for all four land use categories.

Table 5. Options priority weights in the AHP and Fuzzy AHP models

\begin{tabular}{|c|c|c|c|c|}
\hline Land use & \multicolumn{2}{|l|}{ Priority weights in the AHP model } & \multicolumn{2}{|c|}{ Priority weights in the Fuzzy AHP model } \\
\hline \multirow{4}{*}{ Residential } & R-Option A (Ormeau) & 0.2923 & R-Option A (Eagleby) & 0.1146 \\
\hline & R-Option B (Kingsholme Ormeau Station) & 0.2335 & R-Option B (Stapylton) & 0.0987 \\
\hline & R-Option C (Pimpama) & 0.2422 & R-Option C (Ormeau) & 0.1238 \\
\hline & R-Option D (Yawalpah Road) & 0.2320 & R-Option D (Kingsholme Ormeau Station) & 0.1166 \\
\hline \multirow{2}{*}{$\begin{array}{l}\text { Extractive } \\
\text { Industry }\end{array}$} & E-Option A ( KRA 65A1) & 0.5072 & E-Option A ( KRA 65A1) & $\mathbf{0 . 3 8 2 7}$ \\
\hline & E-Option B ( KRA 65B ) & 0.4928 & E-Option B ( KRA 65B ) & 0.3265 \\
\hline \multirow{3}{*}{$\begin{array}{l}\text { Marine } \\
\text { Industry }\end{array}$} & M-Option A (Steiglitz) & 0.4958 & M-Option A (KRA 65A1) & 0.1537 \\
\hline & M-Option B (Northern Gold Coast Marine Precinct) & 0.5042 & M-Option B (Steiglitz) & 0.2844 \\
\hline & & & M-Option C (Northern Gold Coast Marine Precinct) & 0.2824 \\
\hline \multirow{6}{*}{ Recreation } & REC-Option A(Stapylton) & 0.1623 & REC-Option A (Stapylton) & 0.0658 \\
\hline & REC-Option B (Alberton-Gilberton) & 0.1703 & REC-Option B (Alberton-Gilberton) & 0.0703 \\
\hline & REC-Option C (Logan River) & 0.1604 & REC-Option C (Logan River) & 0.0596 \\
\hline & REC_Option D (Corbould Land Trust Nature Refuge) & 0.1812 & REC-Option D (Corbould Land Trust Nature Refuge) & 0.0655 \\
\hline & REC-Option E (Jacobs Well) & 0.1658 & REC-Option E (Jacobs Well) & 0.0666 \\
\hline & REC-Option G (Pimpama) & 0.1600 & REC-Option G (Pimpama) & 0.0611 \\
\hline
\end{tabular}

The initial comparison shows less correlation coefficient for Fuzzy AHP options. This means; in comparison to the conventional AHP, Fuzzy AHP outputs are less sensitive to the criteria weight changes. The differences between two models were more apparent for the 'residential' and 'recreation' categories (Fig. 3a,d ). The least sensitive outputs were observed for

To cite this article: Razieh Mosadeghi, Jan Warnken, Rodger Tomlinson \& Hamid Mirfenderesk, 2015. Comparison of FuzzyAHP and AHP in a spatial multi-criteria decision making model for urban land-use planning, Journal of Computers, Environment and Urban Systems. 49 (2015), 54-65. DOI: 10.1016/j.compenvurbsys.2014.10.001 
the Fuzzy AHP approach in the 'recreation' category with a correlation between criteria weight changes and all the options remained below 0.08 . The AHP model option A, on the other hand, was most sensitive to the REC-C1 changes as indicated by a correlation coefficient of 0.19 (see Fig. 3d). For the 'residential' category the correlation between all the criteria and Fuzzy AHP outputs was less than 0.15 , whereas option A calculated by AHP was almost 2.5 times more sensitive to changes of the weight of the R-C3 criterion (correlation coefficient $=0.36$ ). The stability of the Fuzzy AHP outputs particularly in the 'residential' and 'recreation' categories suggests that; Fuzzy AHP not only presents more reliable outputs, but it would also help to increase the stability of the outcomes where a decision-making model includes more options or alternatives.

The MCDM outputs were more sensitive to the criteria weight changes for the 'extractive industry' category (Fig. 3b), where both models identified only two suitable options. However, Fuzzy AHP still performed slightly better than AHP with the maximum correlation coefficient of 0.5 (between option A and E-C3). The correlation coefficient analysis for the 'marine industry' land use type also showed lower sensitivity for the Fuzzy AHP model.

To cite this article: Razieh Mosadeghi, Jan Warnken, Rodger Tomlinson \& Hamid Mirfenderesk, 2015. Comparison of FuzzyAHP and AHP in a spatial multi-criteria decision making model for urban land-use planning, Journal of Computers, Environment and Urban Systems. 49 (2015), 54-65. DOI: 10.1016/j.compenvurbsys.2014.10.001 

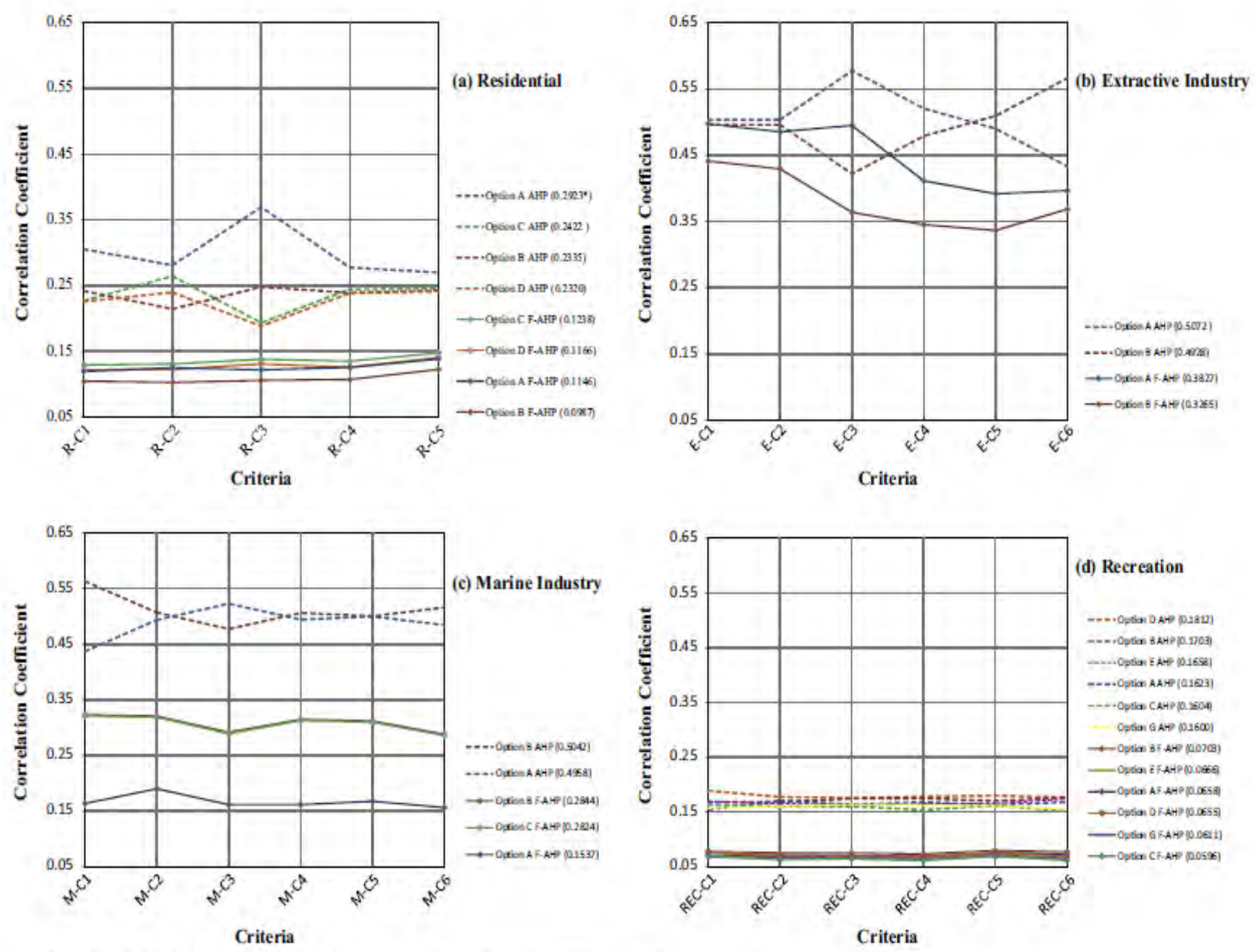

"numbers in this figure represent the criteria weights driven from the MCDM methods

Fig. 3. Comparison of sensitivity analysis in the Fuzzy AHP and AHP models.

The fact that the outputs in the Fuzzy AHP model are less sensitive to the criteria weight changes shows that the degree of domination of these options is almost independent of changes in criteria weights. In other words, the results of sensitivity analysis reaffirmed the findings of Kordi \& Brandt's study (Kordi \& Brandt, 2012) that in general Fuzzy AHP is less sensitive to the criteria weight changes.

To cite this article: Razieh Mosadeghi, Jan Warnken, Rodger Tomlinson \& Hamid Mirfenderesk, 2015. Comparison of FuzzyAHP and AHP in a spatial multi-criteria decision making model for urban land-use planning, Journal of Computers, Environment and Urban Systems. 49 (2015), 54-65. DOI: 10.1016/j.compenvurbsys.2014.10.001 


\subsection{Preferred primary locations for land-use development}

The cogency of using a dual MCDM approach was further highlighted by comparing the location and extent of the preferred options for future development in each category. As the spatial extent of the preferred options in each method were slightly different, to reach the greatest confidence in identifying boundaries of the first priority option, the intersection area between two methods was considered as the most suitable area.

For the residential category for example, both MCDM models identified almost the same area as the most suitable location for further development with a $2.71 \mathrm{~km}^{2}$ intersection area in east Ormeau (Fig. 4). This area contained 4 large land holdings (Fig. 5, boundaries highlighted in red) that is considered the preferred location given its proximity to existing infrastructure and being a reasonable distance from potential natural hazard areas, particularly potential flood affected areas. This area is also located in the vicinity of Ormeau, one of the existing growth corridors within the study area. This output complies with the SEQ regional plan (2009), where land at Ormeau is identified and designated as the growth area within the Gold Coast.

\section{Discussion and conclusion}

This paper examined the application of two MCDM techniques in local land-use planning process for a small area. Implementation of two different MCDM techniques enabled a comparative analysis of the criteria ranking, options priority order, preferred option, and the stability of the results using sensitivity analysis. This research also adds a new dimension to the comparative analysis of MCDM techniques by considering the scale and purpose of the decision-

To cite this article: Razieh Mosadeghi, Jan Warnken, Rodger Tomlinson \& Hamid Mirfenderesk, 2015. Comparison of FuzzyAHP and AHP in a spatial multi-criteria decision making model for urban land-use planning, Journal of Computers, Environment and Urban Systems. 49 (2015), 54-65. DOI: 10.1016/j.compenvurbsys.2014.10.001 
making. This is particularly important in urban planning decisions, where the scale and scope of the planning sets the expectations for identifying the spatial extent of the proposed development.

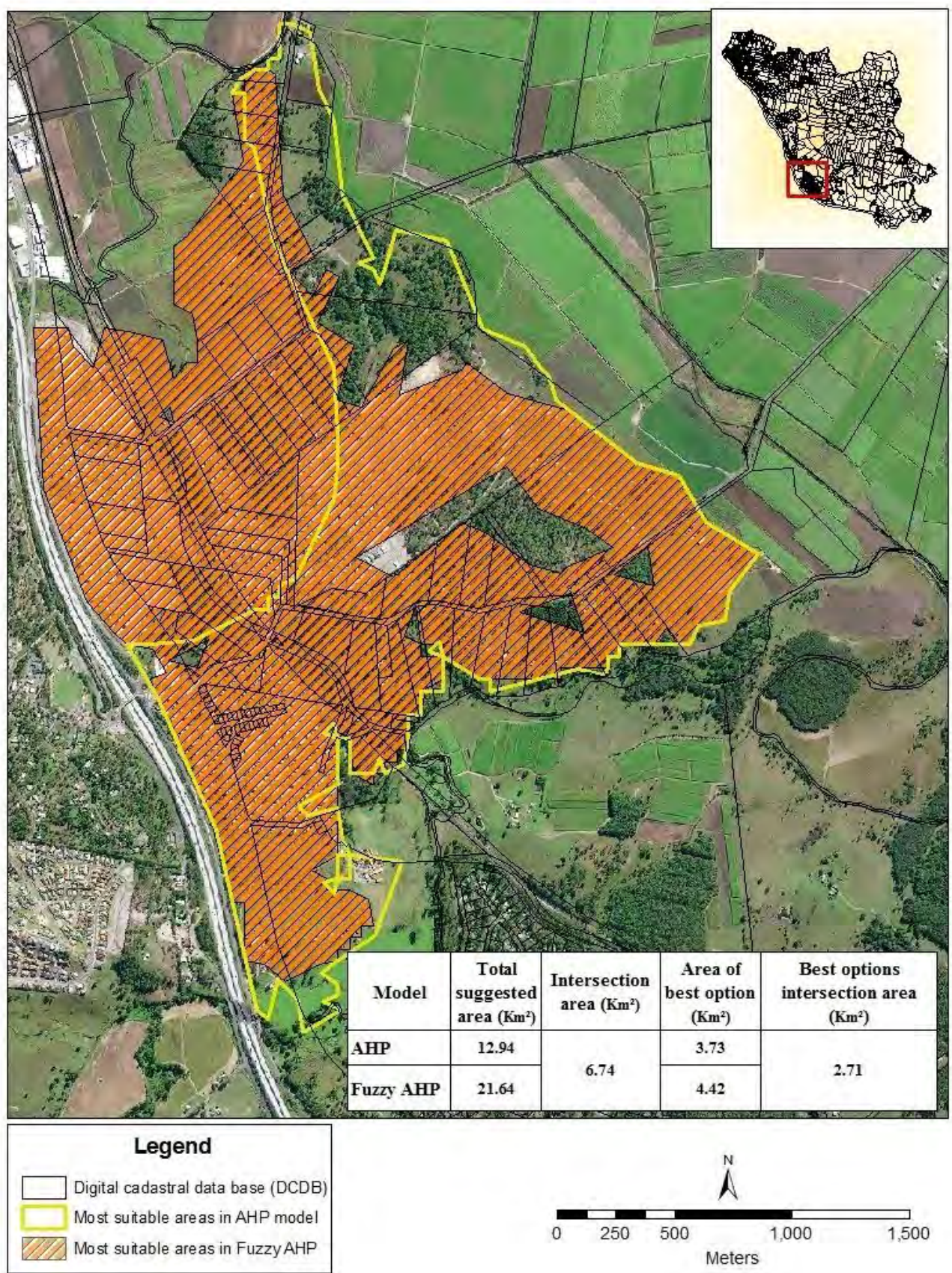

Fig. 4. Residential intersection area of the AHP and Fuzzy AHP models.

To cite this article: Razieh Mosadeghi, Jan Warnken, Rodger Tomlinson \& Hamid Mirfenderesk, 2015. Comparison of FuzzyAHP and AHP in a spatial multi-criteria decision making model for urban land-use planning, Journal of Computers, Environment and Urban Systems. 49 (2015), 54-65. DOI: 10.1016/j.compenvurbsys.2014.10.001 


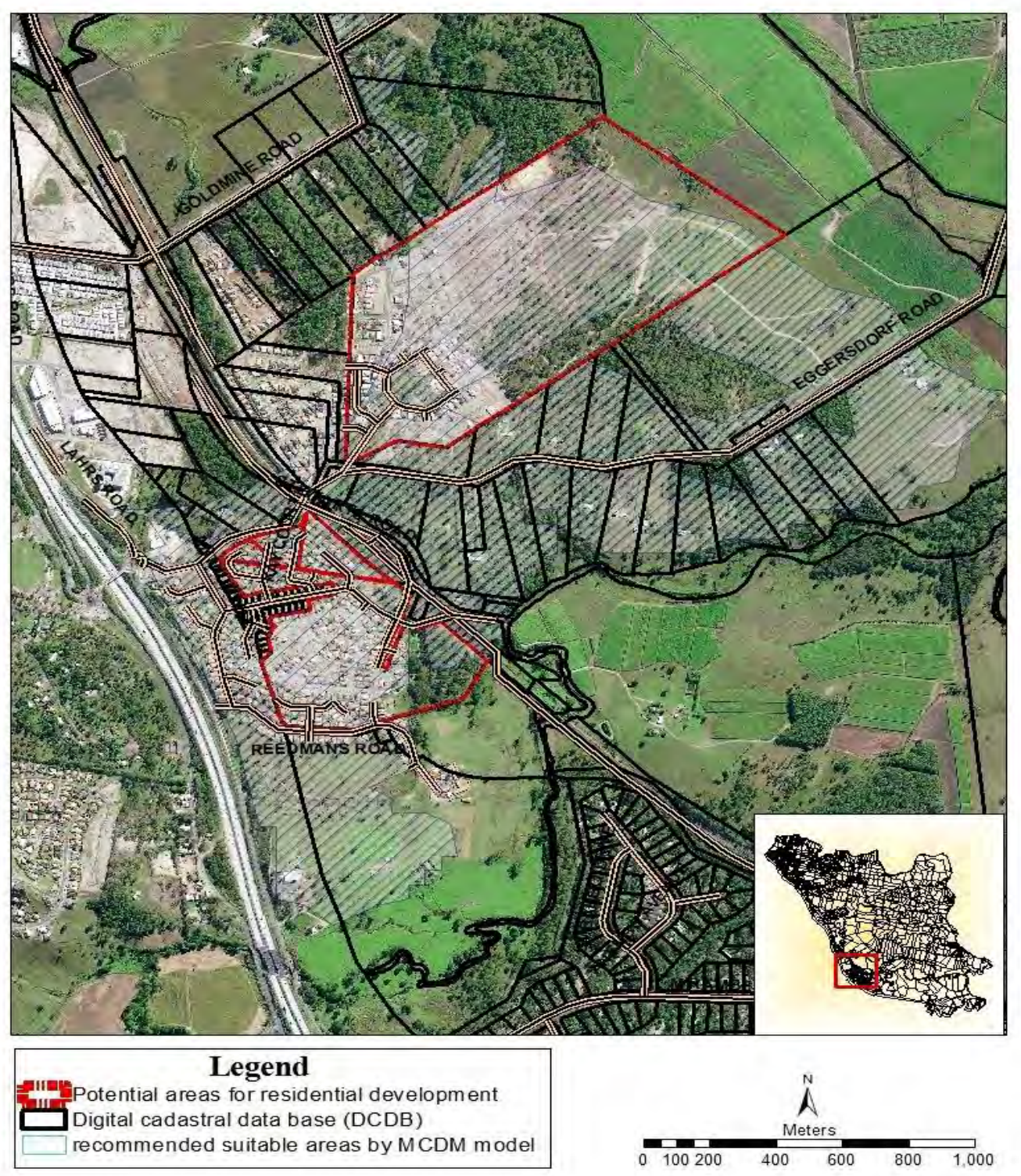

Fig. 5. Recommended land parcels for residential development in the study area.

The result of sensitivity analysis reaffirms the findings of previous studies (e.g. Kordi \&

Brandt, 2012) that, the AHP is sensitive to the uncertainty within the decision model. However,

the comparative analysis in our study showed; differences between criteria ranking in two

models does not necessarily will result in selecting different options (as a focal point) but rather

the differences are more significant in the spatial extent of the selected options. This finding

To cite this article: Razieh Mosadeghi, Jan Warnken, Rodger Tomlinson \& Hamid Mirfenderesk, 2015. Comparison of FuzzyAHP and AHP in a spatial multi-criteria decision making model for urban land-use planning, Journal of Computers, Environment and Urban Systems. 49 (2015), 54-65. DOI: 10.1016/j.compenvurbsys.2014.10.001 
provides a new direction for selecting MCDM method for urban planning purposes. If the planning aims to identify priority areas for development as a focal point, simpler MCDM methods such as AHP should be sufficient. In this situation, selecting more sophisticated techniques like Fuzzy AHP, which can only be seen as a black box by stakeholders, will not necessarily generate different outcomes. Whereas, in more detailed planning, where identifying spatial boundaries is required (such as establishing a master plan), a multiple approach using two or more MCDM techniques would be ideal. In order to reach the greatest confidence in identifying spatial extent of the preferred option, the later approach suggests the intersection area between the outcomes of the two methods as the most suitable area. The findings of this research encourage further research on how applying other quantitative approaches will affect the extent of the proposed development. This is particularly significant in the real-world planning decisions by local governments, as the spatial extent of the proposed development areas triggers the next steps such as land acquisition.

\section{Acknowledgment}

This research was performed as part of a PhD research at Griffith Centre for Coastal Management and partly funded by the Gold Coast City Council. The results of this study do not reflect the official policies and decisions of the Gold Coast City Council and should be seen solely as an academic work.

We would like to acknowledge the anonymous reviewers for their constructive criticism that improved the final version of this paper.

To cite this article: Razieh Mosadeghi, Jan Warnken, Rodger Tomlinson \& Hamid Mirfenderesk, 2015. Comparison of FuzzyAHP and AHP in a spatial multi-criteria decision making model for urban land-use planning, Journal of Computers, Environment and Urban Systems. 49 (2015), 54-65. DOI: 10.1016/j.compenvurbsys.2014.10.001 


\section{References}

Albrechts, L., \& Denayer, W. (2001). Communicative Planning, Emancipatory Politics and Postmodernism. In R.Paddison (Ed.), Handbook of Urban Studies (pp.369-384), London:Sage.

Ananda, J. \& Herath, G. (2008). Multi-attribute preference modelling and regional land-use planning. Ecological Economics, 65(2), 325-335.

Ananda, J. \& Herath G. (2009). A critical review of multi-criteria decision making methods with special reference to forest management and planning. Ecological Economics, 68 (10), 2535-2548.

Arciniegas, G., Janssen, R. \& Omtzigt, N. (2011). Map-based multicriteria analysis to support interactive land use allocation. International Journal of Geographical Information Science, 25(12), 1931-1947.

Baja, S., Chapman, D.M. \& Dragovich, D. (2006). Spatial based compromise programming for multiple criteria decision making in land use planning. Environmental Modeling \& Assessment, 12(3), 171184.

Cacuci, D.G., Ionescu-Bujor, M., \& Navon, I. M., (2003). Sensitivity and Uncertainty Analysis, Applications to Large-Scale Systems. United States of America: CRC Press, Taylor \& Francis Group.

Chang, D.Y., (1996). Application of the extent analysis method on fuzzy AHP. European Journal of Operational Research, 95, 649-655.

Chang, N.B., Parvathinathan, G. \& Breeden, J.B. (2008). Combining GIS with fuzzy multicriteria decision-making for landfill siting in a fast-growing urban region. Journal of Environmental Management, 87(1), 139-53.

Chen, X.H., 2005. A research based on Fuzzy AHP for Multi-criteria supplier selection in supply chain. Thesis (Master degree). Taiwan National University of Science and Technology.

Chen, H., Wood, M.D, Linstead, C., \& Maltby, E. (2011). Uncertainty analysis in a GIS-based multicriteria analysis tool for river catchment management. Environmental Modelling \& Software, 26 (4), 395-405.

Chen, Y., Yu, J. \& Khan, S. (2010). Spatial sensitivity analysis of multi-criteria weights in GIS-based land suitability evaluation. Environmental Modelling \& Software, 25(12), 1582-1591.

Collins, M.G., Steiner, F.R. \& Rushman, M.J. (2001). Land-use suitability analysis in the United States: historical development and promising technological achievements. Environmental Management, 28(5), 611-21.

Dermirel, T., Demirel, N.C., and Kahraman, C. (2009). Fuzzy analytic hierarchy process and its application. In:Kahraman, C., ed. Fuzzy Multi-Criteria Decision Making: Theory and Applications with Recent Developments. New York: Springer. 53-84.

Deng, H. (1999). Multicriteria analysis with fuzzy pairwise comparison. International Journal of Approximate Reasoning, 21(3), 215-231.

Dunning, D.J., Ross, Q.E. \& Merkhofer, M.W. (2000). Multiattribute utility analysis for addressing Section 316(b) of the Clean Water Act. Environmental Science \& Policy, 3, S7-S14.

Elaalem, M., Comber, A., Fisher, P. (2010). Land evaluation techniques comparing Fuzzy AHP with TOPSIS methods. In: Proceedings of $13^{\text {th }}$ AGILE International Conference on Geographic Information Science Guimaraes, Portugal, 1-8.

Elaalem, M. (2013). A Comparison of Parametric and Fuzzy Multi-Criteria Methods for Evaluating Land Suitability for Olive in Jeffara Plain of Libya. APCBEE Procedia, 5, 405-409.

Ertuğrul, İ. \& Karakaşoğlu, N. (2008). Comparison of fuzzy AHP and fuzzy TOPSIS methods for facility location selection. The International Journal of Advanced Manufacturing Technology, 39(7-8), 783795.

To cite this article: Razieh Mosadeghi, Jan Warnken, Rodger Tomlinson \& Hamid Mirfenderesk, 2015. Comparison of FuzzyAHP and AHP in a spatial multi-criteria decision making model for urban land-use planning, Journal of Computers, Environment and Urban Systems. 49 (2015), 54-65. DOI: 10.1016/j.compenvurbsys.2014.10.001 
Figueira, J.R., Greco, S., Roy, B., and Slowinski, R. (2010). ELECTRE methods: main features and recent developments. In: Zopounidis, C., and Pardalos, P., eds. Handbook of Multicriteria Analysis. Berlin, Springer. 51-86.

Greene, R., Luther, J.E., Devillers, R., \& Eddy, B. (2010). An approach to GIS-based multiple criteria decision analysis that integrates exploration and evaluation phases: Case study in a forest-dominated landscape. Forest Ecology and Management, 260(12), 2102-2114.

Haghighi, M., Divandari, A., \& Keimasi, M. (2010). The impact of 3D e-readiness on e-banking development in Iran: A fuzzy AHP analysis. Expert Systems with Applications, 37, 4084-4093.

Hajkowicz, S., McDonald, G.T., and Smith, P.N. (2000). An evaluation of multiple objective decision support weighting techniques in natural resource management. Journal of Environmental Planning and Management, 43(4), 505-518.

Hajkowicz, S., \& Collins, K. (2006). A Review of Multiple Criteria Analysis for Water Resource Planning and Management. Water Resources Management, 21(9), 1553-1566.

Herath, G., \& Prato T. (2006). Using Multi-criteria decision analysis in natural resource management. Burlington: Ashgate publisher.

Hillier J. (2002). Shadows of Power: An Allegory of Prudence in Land-Use Planning. London/NewYork: Routledge.

Janssen, R., Herwijnen, M., Stewart, T.J., \& Aerts, J.C.J.H. (2008). Multiobjective decision support for land-use planning. Environment and Planning B: Planning and Design, 35(4), 740-756.

Janssen, J.A.E.B, Krol, M.S., Schielen, R.M.J., \& Hoekstra, A.Y. (2010). The effect of modelling expert knowledge and uncertainty on multicriteria decision making: a river management case study. Environmental Science \& Policy, 13 (3), 229-238.

Jie, H. L., Meng, M.C., \& Cheong, C.W. (2006). Web Based Fuzzy Multicriteria Decision

Making Tool. International Journal of the Computer, the Internet and Management, 14(2), 1-14.

Joerin, F. (2001). Using GIS and outranking multicriteria analysis for land-use. International Journal of Geographical Information Science, 15(2), 153-174.

Kalogirou, S. (2002). Expert systems and GIS: an application of land suitability evaluation. Computers, Environment and Urban Systems, 26(2-3), 89-112.

Keshavarzi, A. \& Heidari, A. (2010). Land suitability evaluation using Fuzzy continuous classification ( a case study : Ziaran region ). Modern Applied Science, 4(7), 72-82.

Kordi, M. \& Brandt, S.A. (2012). Effects of increasing fuzziness on analytic hierarchy process for spatial multicriteria decision analysis. Computers, Environment and Urban Systems, 36(1), 43-53.

Lahdelma, R., Makkonen, S. \& Salminen, P. (2009). Two ways to handle dependent uncertainties in multi-criteria decision problems. Omega , 37(1), 79-92.

Malczewski, J. (2004). GIS-based land-use suitability analysis: a critical overview. Progress in Planning, 62(1), 3-65.

Malczewski, J. (2006). Ordered weighted averaging with fuzzy quantifiers: GIS-based multicriteria evaluation for land-use suitability analysis. International Journal of Applied Earth Observation and Geoinformation, 8(4), 270-277.

Marinoni, O. (2004). Implementation of the analytical hierarchy process with VBA in ArcGIS. Computers \& Geosciences, 30(6), 637-646.

Mikhailov, L. (2003). Deriving priorities from fuzzy pairwise comparison judgements. Fuzzy Sets and Systems, 134(3), 365-385.

Mosadeghi, R., Tomlinson R., Mirfenderesk, H., \& Warnken, J. (2009). Coastal Management Issues in Queensland and Application of the Multi-Criteria Decision Making Techniques. Journal of Coastal Research, SI56, 1252-1256.

To cite this article: Razieh Mosadeghi, Jan Warnken, Rodger Tomlinson \& Hamid Mirfenderesk, 2015. Comparison of FuzzyAHP and AHP in a spatial multi-criteria decision making model for urban land-use planning, Journal of Computers, Environment and Urban Systems. 49 (2015), 54-65. DOI: 10.1016/j.compenvurbsys.2014.10.001 
Prakash, T.N. (2003). Land suitability Analysis for Agricultural Crops: A fuzzy Multicriteria Decision Making Approach. Thesis (Master). The institute for Geo-information Science and Earth observation, the Netherlands.

Quadros, T.F.P., Koppe, J.C., Strieder, A.J., and Costa, J.F.C.L. (2006). Mineral-potential mapping: a comparison of weights-of-evidence and Fuzzy methods. Natural Resource s Research, 15(1), 49-66.

Queensland government, Department of Infrastructure and Planning, (2008). North-East Gold Coast strategic land use, economic development and infrastructure study, Terms of References, office of urban management $<$ http://www.dsdip.qld.gov.au/resources/plan/seq/north-east-gold-coaststudy/negc-landuse-strategy-2009.pdf $>$ (Accessed July 14 2010).

Queensland government, Department of Infrastructure and Planning, (2009). South-east Queensland Regional Plan 2009-2031 < http://www.dsdip.qld.gov.au/regional-planning/south-east-queenslandregional-plan-2009-2031.html $>$ (Accessed September 23, 2010).

Saaty, T.L. \& Vargas, L.G. (2001). Models, Methods, Concepts and Applications of the Analytic hierarchy process: Springer.

Saltellie, A. Chan, K., \& Scott, E.M. (2000). Sensitivity Analysis. England: John Wiley \& Sons, Ltd.

Saltellie, A., Tarantola, S., Campolongo, F., \& Ratto, M. (2004). Sensitivity Analysis In Practice, A Guide to Assessing Scientific Models. England: John Wiley \& Sons, Ltd.

Steele, K., Carmel, Y., Cross, J., \& Wilcox, C. (2009). Uses and misuses of multicriteria decision analysis (MCDA) in environmental decision making. Risk Analysis, 29(1), 26-33.

Sui, D.Z. (1992). A Fuzzy GIS modeling approach for urban land evaluation. Computers, Environment and Urban Systems, 16, 101-115.

Svoray, T., Bar Kutiel, P. \& Bannet, T. (2005). Urban land-use allocation in a Mediterranean ecotone: Habitat Heterogeneity Model incorporated in a GIS using a multi-criteria mechanism. Landscape and Urban Planning, 72(4), 337-351.

Thapa, R.B. \& Murayama, Y. (2008). Land evaluation for peri-urban agriculture using analytical hierarchical process and geographic information system techniques: A case study of Hanoi. Land Use Policy, 25(2), 225-239.

Wang, T.C. \& Chen, Y.H. (2008). Applying fuzzy linguistic preference relations to the improvement of consistency of fuzzy AHP. Information Sciences, 178(19), 3755-3765.

Wu, F.G., Lee, Y.J. \& Lin, M.C. (2004). Using the fuzzy analytic hierarchy process on optimum spatial allocation. International Journal of Industrial Ergonomics, 33(6), 553-569.

Zarghami M., Szidarovszky F., \& Ardakanian R. (2008). A fuzzy-stochastic OWA model for robust multi-criteria decision making. Fuzzy Optimization and Decision Making, 7, 1-15.

Zhang, K. \& Achari, G. (2010). Uncertainty propagation in environmental decision making using random sets. Procedia Environmental Sciences, 2, 576-584.

Zopounidis, C. \& Doumpos, M. (2002). Multicriteria classification and sorting methods: A literature review. European Journal of Operational Research, 138(2), 229-246.

Yang C.C. \& Chen B.S. (2004), Key Quality Performance Evaluation Using Fuzzy AHP. Journal of the Chinese Institute of Industrial Engineers, 21(6), 543-550.

To cite this article: Razieh Mosadeghi, Jan Warnken, Rodger Tomlinson \& Hamid Mirfenderesk, 2015. Comparison of FuzzyAHP and AHP in a spatial multi-criteria decision making model for urban land-use planning, Journal of Computers, Environment and Urban Systems. 49 (2015), 54-65. DOI: 10.1016/j.compenvurbsys.2014.10.001 